\title{
The EU as a Regional Actor: The Case of the Czech Republic
}

\author{
DAN MAREK \\ Palacky University \\ MICHAEL BAUN \\ Voldosta State University
}

\begin{abstract}
This article examines the impact of EU enlargement on regionalization in the Czech Republic. It asks whether pre-accession preparations for EU regional policy have promoted regionalization and governmental decentralization in the Czech Republic, a question prompted by the debate about EU regional policy and regionalization in the current Member States. After reviewing Czech preparations for EU regional policy and the administration of pre-accession structural aid programmes, it concludes that the EU's impact on regionalization in the Czech Republic has been both limited and highly ambivalent. The article thus confirms the findings of previous research on EU enlargement and regionalization in the candidate countries.
\end{abstract}

\section{Introduction}

The impact of the European Union (EU) on regionalization has been the subject of considerable debate. Some scholars claim that EU regional policy has been a major factor in the shift of political authority and activity from the national to regional level in Europe. EU policies, they argue, have promoted governmental decentralization and strengthened regional authorities vis-àvis national governments, thereby contributing to the emergence of a 'Europe of the Regions' (Jones and Keating, 1995; Hooghe, 1996; Marks, 1992, 1993; Marks et al., 1996; Hooghe and Marks, 2001). Others are sceptical of these claims. They argue that the impact of EU regional policy varies considerably from country to country, in accordance with such factors as Member State size, governmental traditions, and existing territorial and constitutional arrangements. They also point to the ability of national governments to act as 'gatekeepers,' thus limiting the impact of EU policies on domestic politics (Bache, 1998; Pollack, 1995; Jeffery, 997; Börzel, 1999; Benz and Eberlein, 1999; Evans, 2001). 
The debate about the EU and regionalization has largely focused on the current Member States. As several recent studies have noted, however, EU policies can also affect regionalization and the development of territorial governance structures in the candidate countries for accession (Brusis 2001a, b; Grabbe, 2001; Hughes et al., 2001). This is the case for several reasons. First, the institutional and administrative requirements of EU regional policy are a key part of the voluminous acquis communautaire that the candidate states must adopt as a condition of membership. These requirements include the possession of a regionalized administrative capacity, including the existence of competent regional authorities that can serve as partners of the Commission and national governments in the management of EU structural programmes. Second, in most of the central and eastern European countries (CEECs) that are candidates for accession, the regional (or meso) level of government - between the central state and local levels - was seriously underdeveloped or neglected following the collapse of communism. These countries have thus had to create or rebuild regional institutions in order to meet EU accession requirements, often with little in the way of national traditions of regional governance to build upon. Third, the CEECs have had to adopt EU rules and standards in a relatively short period of time, increasing their openness to EU influence.

These studies also argue, however, that the EU's impact on regionalization in the CEECs has thus far been limited. One reason for this is the absence of a clear or uniform EU model, with current Member States offering a great variety of regional governance models to emulate or choose from. Another is the absence of indigenous or bottom-up pressures for regionalization in the CEECs, in contrast to the situation in western Europe. Instead, in most CEECs regionalization has generally been a top-down process, imposed from outside the EU and by central governments, without the active participation of local and regional interests. ${ }^{1}$ Finally, regionalization in the CEECs has been undermined by the technocratic nature of the accession process and the contradictions of the EU's own requirements and demands. While promoting the norms of regional self-governance and decentralization, the EU also emphasizes the speedy completion of accession preparations and the efficient use of EU resources, thus creating incentives for centralization and strengthening national government authorities vis-à-vis regional actors and interests (Brusis, 2001a, b; Grabbe 2001; Hughes et al., 2001).

This article looks more closely at the question of EU enlargement and regionalization in the CEECs, through a case study of the Czech Republic. After briefly discussing the key requirements of EU regional policy that the candidate countries must meet, it examines the institutional adaptations made

\footnotetext{
${ }^{1}$ A possible exception in this regard may be Poland (Brusis, 2001a; Hughes et al., 2001; Yoder, 2001). (c) Blackwell Publishers Ltd 2002
} 
by the Czech government in preparation for EU regional policy, including the creation of a new system of regional self-governance. The article then examines the administration of EU pre-accession aid programmes in the Czech Republic since the early 1990s and the preparation of the National Regional Development Plan (NDP) for 2004-06. In each instance, it seeks to determine the extent to which EU requirements and influence have promoted decentralization and affected the development of centre-region relations. The article concludes that the EU's impact on regionalization in the Czech Republic has thus far been highly ambivalent: while the EU has required or supported the creation of new regional institutions in preparation for membership, the accession process has also favoured the centralized administration of pre-accession programmes and discouraged effective decentralization. This case study of the Czech Republic thus confirms the findings of previous research regarding the limited and sometimes contradictory impact of EU enlargement on regionalization in the CEECs. The conclusion also discusses the future prospects for regionalization in the Czech Republic.

\section{Regional Policy, Regionalization and Enlargement}

Regional (or 'structural and cohesion') policy is a central aspect of the EU's acquis communautaire. It is also a major component of the EU budget, with expenditure on 'structural operations' currently accounting for nearly 35 per cent of EU spending in 2002 (Commission, 2002a, p. 7).

The primary instrument of EU regional policy, accounting for more than 90 per cent of all structural spending, is the structural funds. Money under this category is allocated to meet three key 'objectives,' by far the most important being objective 1 - promoting development in economically backward regions, with a per capita GDP of less than 75 per cent of the EU average. The other two objectives are assistance to regions facing economic and social restructuring (objective 2), and aid to Member States in developing human resources to fight unemployment (objective 3). A small portion (5 per cent) of the structural funds is allocated for 'Community initiative' programmes that are devised by the Commission to meet outstanding regional needs, with the programme to promote cross-border, transnational and inter-regional cooperation (Interreg) being the largest and most well known. The EU also provides cohesion fund assistance to its poorest Member States, with a per capita GDP of less than 90 per cent of the EU average.

Before they can join the EU, the candidate states must meet the institutional and administrative requirements of EU regional policy, covered in chapter 21 ('Regional Policy and Co-ordination of Structural Instruments') in the accession negotiations. These requirements mainly concern administrative 
capacity, and include an appropriate legal framework, effective systems of financial control, and the availability of sufficient financial (for co-financing) and human resources. ${ }^{2}$ Also required are effective inter-ministerial coordinating mechanisms for regional policy, multi-annual programming capacity, and adequate means for monitoring and evaluating structural programmes. The candidate countries must also design a national regional development plan. Another requirement is that they organize their territory according to the EU's NUTS ${ }^{3}$ system of statistical classification, which is used for implementation of the structural funds.

The administrative requirements of the structural funds also include a regionalized system of administration, with the existence of competent regional bodies that can serve as partners of the Commission and national governments in the management of EU structural programmes. The partnership principle is a key governing principle of the structural funds, and requires the participation of appropriate regional and other sub-national actors (local governments, economic and social partners, NGOs) in all aspects of the administration and management of the funds, including planning, implementation, monitoring and evaluation. The goal of the partnership principle is regional policy not just for the regions, but by them as well; rather than being made in a centralized or top-down fashion by national capitals and administrative bureaucracies, regional policy should be a decentralized and collaborative process involving the regional and local target constituencies of structural policy. The partnership principle does not apply to non-structural funds programmes, however, such as the cohesion fund.

While it requires regionalized administrative structures for management of the structural funds, the EU has not sought to define these. Nor has the EU sought to impose a uniform model or template for regional governance on the Member States, instead taking the position that this is an internal matter for the Member States in which it has no legal competence. It has therefore given national governments wide latitude in the design of regional administrative structures, allowing them to designate the appropriate regional authorities for partnership in accordance with national conditions, traditions and constitutional frameworks. This approach has also been followed in the EU's preaccession advice to the candidate states. The Commission merely requires that 'appropriate' systems of regional administration and governance be in place by the time of accession, without trying to define these in any concrete way. However, in its regular progress reports and through other means, the Commission has also made clear its preference for democratically elected regional governments that possess a substantial amount of financial and legal

\footnotetext{
${ }^{2}$ The requirements for regional and cohesion policy are detailed in Commission (2002b).

${ }^{3}$ la Nomenclature des Unités Territoriales Statistiques.

(c) Blackwell Publishers Ltd 2002
} 
autonomy. This is in keeping with the Commission's own views on the conditions for democratic stability in the CEECs and the requirements of the partnership principle (Brusis, 2001b, pp. 12-13 and 24-5).

\section{Preparing for EU Regional Policy in the Czech Republic}

Before 1998, regional policy in the Czech Republic was limited in both size and scope (Péteri and Simek, 2000). Regional policy planning was also heavily centralized, involving only state administration bodies at the national and local (county) level. Self-governing regions did not exist, and non-governmental actors in the regions were excluded from the planning process. In the absence of administrative regions that were comparable to the EU's NUTS II 'cohesion' regions, target areas for structural assistance were selected at the county level (equivalent to NUTS IV), a much lower level for regional policy planning and administration than in the EU.

Czech authorities explained the absence of a comprehensive regional policy by arguing that the Czech Republic 'belongs to the countries with the lowest inter-regional disparities in Europe (despite its lower overall economic performance) and regional development measures thus carry lower political priority' (MRD, 1998, p. 30). ${ }^{4}$ It was also due to political factors, however. The government of Prime Minister Václav Klaus (1992-97) emphasized neo-liberal macroeconomic policies and displayed an ideological aversion to 'interventionist' and redistributive regional policies. The Klaus government also preferred a centralist approach to government policy-making, and was thus reluctant to create a decentralized institutional framework for regional policy (Jacoby and Cernoch, 2002; Brusis, 2001a, p. 14; Brusis 2001b, p. 17).

Unsurprisingly, therefore, in its July 1997 'opinion' on the Czech Republic's application for EU membership the Commission declared that 'the Czech Republic lacks an independent regional development policy'. The Commission noted the absence of necessary institutional and administrative structures for regional policy, including inter-ministerial co-ordination mechanisms at the national level (although it applauded the recent creation of a Ministry for Regional Development: MRD), and it pointed to the absence of elected governmental bodies between the central state and local (commune) levels that could serve as partners of the national government and the Commission for implementing regional policy. It also noted the inadequacy of financial

${ }^{4}$ In fact, in 1998 the Czech Republic had a national per capita GDP that was 60.3 per cent of the EU average, while regional per capita income (excluding the Prague region) ranged from 46.9 per cent (Central Bohemia) to 57.4 per cent (Southwest Bohemia) of the EU average. With a per capita GDP of 114.7 per cent of the EU average, the Prague region alone (among all CEEC regions) would not qualify for objective 1 assistance at this point in time. Per capita GDP figures cited in Commission (2001a), 'Statistical Annex, Tables', p. 48. 
resources and instruments for regional policy, and the absence of an appropriate and sufficient legal basis (Commission, 1997a, pp. 64-5, 83-4). Thus, in its 1998 accession partnership document for the Czech Republic, the Commission identified the development of an institutional capacity for regional policy as a key goal to be achieved before accession (Commission, 1998a). This goal was subsequently incorporated into the Czech government's 'National Programme for Adoption of the Acquis Communautaire' (Czech Republic Government, 1998).

The Czech government's preparations for EU regional policy began after its formal application for membership in 1996, but intensified after the beginning of accession negotiations in early 1998 (Czech Republic Government, 1999; MRD, 1999). Meeting EU requirements in this area has posed a major challenge. According to an internal government document, "it involves a number of tasks in institution building, including adoption of the necessary policies, strategies and programmes and establishment of appropriate administrative structures and mechanisms' (MRD, n.d., 2).

Among the key steps taken by the Czech government was the establishment of the MRD in November 1996. The MRD's main task is to co-ordinate the government's preparations for EU regional policy, including drafting the National Regional Development Plan (NDP), the basic multi-year programming document for EU pre-accession and structural funds assistance. The MRD is also the primary agency responsible for implementing national regional development policy. Within the MRD, the Centre for Regional Development is the agency responsible for co-ordinating all regional development activities. An inter-ministerial committee chaired by the Minister for Regional Development - the National Management and Co-ordination Committee was created and given responsibility for co-ordinating preparation of the basic programming documents necessary for the structural funds. This body will also function as the Monitoring Committee for structural funds programmes at the national level.

The Czech government has also created a regionalized structure for administering EU structural development programmes. A network of Regional Development Agencies (RDAs) was established beginning in 1998. Also created was a network of 14 Regional Co-ordination Committees (corresponding to the newly created self-governing regions - see below - and composed of the representatives of regional and national government authorities) to work with the RDAs and manage the preparation of regional development strategies that will contribute to the NDP.

Another key step has been the creation of a new system of regional selfgovernance. This was mandated by the 1993 Constitution, whose authors viewed governmental decentralization and the diffusion of power as a major 
democratic goal (Blazek and Boekhout, 2000, pp. 309-10; cited in Jacoby and Cernoch, 2002). Thus, Article 99 declares that 'the Czech Republic is composed of municipalities which are the basic territorial administrative units and regions which are higher territorial administrative units' (emphasis added). At the time, however, these regional units did not exist.

The political debate on regional reform after 1993 focused mainly on the number and territorial delineation of the new regions, and less on their specific competencies. Some early support existed for self-government of the historic regions of Bohemia, Moravia and Silesia, but this option was eventually rejected in favour of more functionally defined regions. One reason for this decision (in the wake of the 1993 split with Slovakia) was the fear that decentralization along historic region lines would promote the nascent movement for Moravian independence and exacerbate Bohemian-Moravian tensions.

Among the political parties, Prime Minister Klaus' Civic Democratic Party (ODS) was the most sceptical about the merits of regionalization, because of its centralist preferences and concern that the creation of regional authorities would bring about a significant increase of bureaucracy. ${ }^{5}$ Its government coalition partners - the Christian Democrats (KDU-CSL) and the Civic Democratic Alliance (ODA) - were both more strongly in favour of decentralization and wanted a speedy creation of regional authorities. They differed mainly on the number of regions, with the Christian Democrats favouring the creation of nine regions and the ODA 13. By contrast, the ODS sought to minimize the potential clout of the new regional authorities by maximizing their number. In June 1994, the ODS proposed turning the 75 counties (districts) into regions, but this was strongly rejected by its coalition partners. A subsequent ODS proposal to create 17 regions was rejected by the Parliament in June 1995. The opposition Social Democrats also strongly favoured devolution, advocating a system of nine regions. With the exception of the Communists and the extreme right, all other parties supported the creation of regional authorities and fulfilment of the Constitution. President Václav Havel also sided with the proponents of decentralization in this debate, while refraining from stating a detailed position on the issue. ${ }^{6}$

An agreement on regional reform was finally reached among the government parties and the Social Democrats in October 1997. The resulting 'Constitutional Act on the Formation of the Regions' called for dividing the Czech Republic into 14 regions ('Higher Self-Governing Units'), or kraj, each with their own elected assemblies (see Map 1). The agreement represented a com-

\footnotetext{
${ }^{5}$ For an excellent account of the positions of the individual parties on the reform of regional administration, see Saradin and Sulák (2001).

${ }^{6}$ In November 1992, however, he expressed support for a system based on seven regions.

(c) Blackwell Publishers Ltd 2002
} 
promise between those favouring a larger number of regions - including opponents of regionalization such as Klaus, and self-interested regional and local politicians, who wanted to maximize the number of new political positions - and those favouring a smaller number. The latter argued that a smaller number of larger regions would be more effective, while also being more aligned with EU regional policy requirements regarding the compatibility of administrative and cohesion regions. The goal of undercutting historicallybased autonomy movements also resulted in some regional boundaries being drawn across traditional Bohemian-Moravian lines (Jacoby and Cernoch, 2002; Moxon-Browne and Kreuzbergova, 2001, pp. 12-15).

The law creating the new regions was supposed to take effect in January 2000. However, while the minority Social Democratic government that was installed following the elections of June 1998 was more sympathetic to regionalization, delays in approving the necessary legislation on state administration reform meant that the new regional authorities did not begin functioning until January 2001. The regional governments have been given competencies in the areas of education, culture, regional development, transport, agriculture, environment and health care. However, debate continues over the precise delineation of competencies and the division of powers between the national government and regional authorities. Financing arrangements for the new regional authorities also remain to be settled.

The EU's impact on the regional reform debate is difficult to determine with any degree of precision. The Commission strongly favoured the exist-

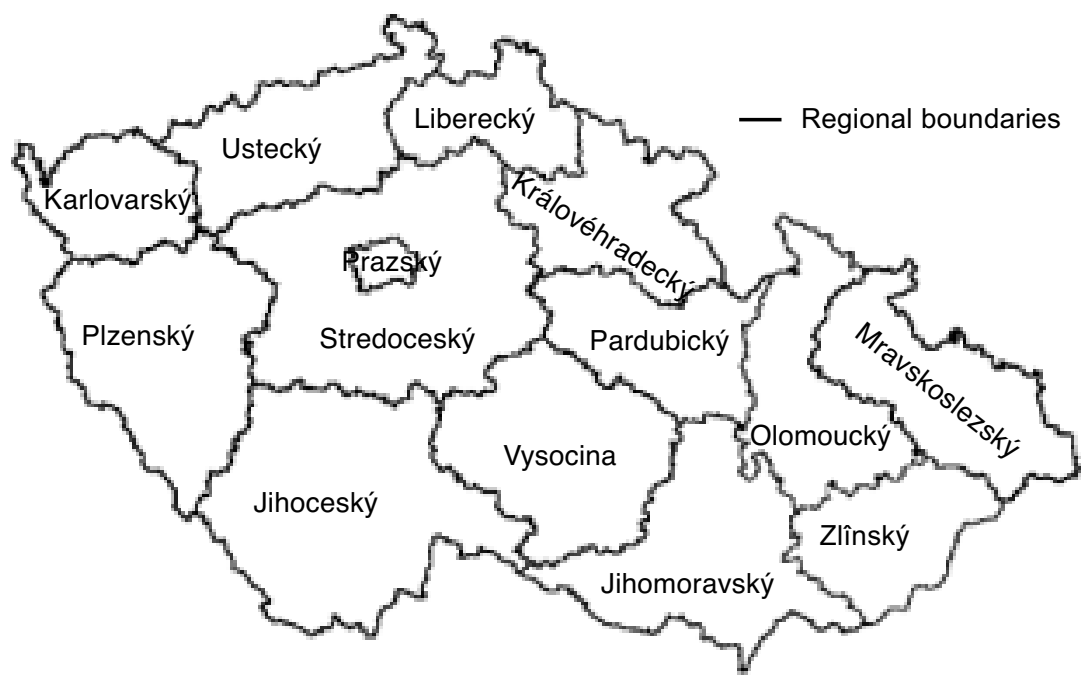

Map 1: Higher Self-Governing Regions in the Czech Republic 
ence of self-governing regions and made this preference known. In its 1997 opinion, for instance, the Commission pointedly noted the absence of 'elected' bodies between the central state and commune (local) levels (Commission, 1997a, pp. 64-5). Nevertheless, while the Commission's views provided decentralization proponents with additional arguments and support, the constitutionally mandated creation of new regional authorities already had considerable domestic support and may have occurred anyway. This is impossible to say for certain, however. It may well be the case that a narrow window of opportunity for regional reform existed after 1993, amidst the new enthusiasm for democratization and civil society, and this may have closed without the pressure of EU accession, as post-communist reformers left the stage and centralist governmental traditions reasserted themselves. At the very least, EU pressure and the prospect of accession probably accelerated the process of regionalization in the Czech Republic. In the regional reform debate, the EU's requirement of compatibility between administrative and cohesion regions was also used as an argument for creating a smaller number of regions, but this apparently had little influence on the final outcome.

The new regional bodies were intended to be key partners of the Commission and national government authorities in planning and implementing EU regional policy. However, with an average population of 800,000, compared to the EU average for NUTS II regions of 2.5 million, the number of $k r a j$ created was greater than necessary for the purposes of EU regional policy. As a result, some regions have had to be combined into larger cohesion regions for administration of the structural funds. An October 1998 government resolution (No. 707) established, in line with EU methodology, eight NUTS II regions, which are the basic units eligible for objective 1 assistance under the structural funds (see Map 2). These eight cohesion regions were created by grouping together the fourteen new kraj, which were designated as NUTS III territorial units. The 14 Regional Co-ordination Committees will be integrated into eight Regional Management and Monitoring Committees (Regional Councils) that will prepare the regional operational programmes (ROPs) necessary for securing objective 1 assistance. The Regional Councils will also appoint Regional Development Committees to monitor EU structural programmes.

The amalgamation of the $14 \mathrm{kraj}$ into eight cohesion regions creates a potentially awkward situation by grouping together, in some of the NUTS II units, regions which have not always historically co-operated, and in some cases have even been rivals. The need to co-operate among regional authorities could place amalgamated NUTS II units at a severe disadvantage in the competition for EU structural assistance with more homogenous units that incorporate only one self-governing region (Moxon-Browne and Kreuzbergova, 2001, p. 14). 


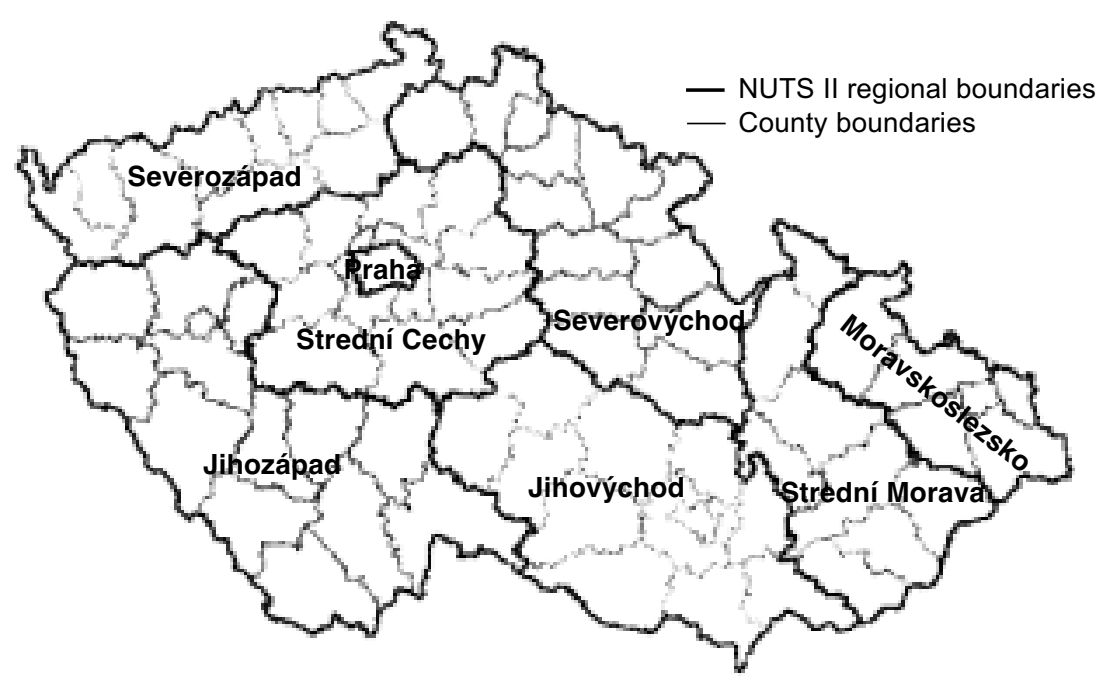

Map 2: NUTS II Regions in the Czech Republic

The Czech government's preparations for EU regional policy have been noted approvingly by the Commission in its annual regular reports on the Czech Republic's progress towards accession. However, the Commission has also criticized various aspects of these preparations, primarily in the areas of financing, financial management and control, and administrative resources and procedures. It has also expressed concern about the uncertain division of responsibilities between authorities at the two regional levels (NUTS II and III), and noted continued questions about the powers and role of the newly elected regional governments (Commission, 1998b, pp. 30, 40; 1999a, pp. 48, 70; 2000, p. 82; 2001b, p. 82). The Commission's October 2000 report was generally more positive about each of these issues, although it expressed continuted doubts about administrative capacity for implementing the structural funds (Commission, 2002c, pp. 100-2).

Thus, by the end of 2002 the Czech Republic has made substantial progress towards meeting the institutional and administrative requirements of EU regional policy, including the establishment of a system of regional governance and regionalized structures for implementing EU structural assistance programmes. It remains to be seen, however, to what extent these new decentralized structures will be actually utilized and the partnership principle applied in the management of the structural funds after accession. The Czech Republic's experience in implementing pre-accession structural assistance programmes and in formulating the NDP may provide some indication of this. It is to these two cases that we now turn. 


\section{Administering Pre-Accession Aid in the Czech Republic}

EU pre-accession aid has been channelled into the Czech Republic via three major programmes: Phare (Poland and Hungary: Aid for the Restructuring of Economies), Ispa (Instrument for Structural Policies for Pre-Accession), and Sapard (Special Action Programme for Pre-accession Aid for Agriculture). Since not all of these programmes were designed along the lines of the structural funds, application of the partnership principle in their implementation was not always required, although in some cases it was. Nevertheless, the experience of these programmes may provide some indication of attitudes regarding the partnership idea and decentralization in the Czech Republic, as well as reveal tendencies in the development of centre-region relations.

\section{Phare}

The Phare programme has been the most important instrument of EU financial support for the Czech Republic and other CEECs in the pre-accession period. Originally established in 1989 to support political and economic reforms in Poland and Hungary, Phare was 'the first [EU aid] instrument explicitly to take account of the more dramatic changes that unfolded in 1989' (Sedelmeier and Wallace, 1996, p. 357). Czechoslovakia's accession to the programme in 1990 provided it (and later the Czech Republic) with a qualitatively higher framework for co-operation with the EU (Commission, 1990a, 1997b).

Phare's orientation until 1998 was 'demand-driven', focusing on funding priorities selected by the CEECs that were compliant with the Commission's assessment of each country's needs. These included: 'industrial restructuring, the environment (pollution control, industrial waste, nuclear safety), energy, training and youth exchange, investment (transport and telecommunications), scientific and technical co-operation, and improved access to markets' (Commission 1990b, p. 13). From the beginning of its operation in the Czech Republic, Phare also included priorities with a regional dimension. These were not initially defined in a way to achieve compatibility with EU regional policy, however. Instead, the programme's regional initiatives focused on two major activities with different eligibility criteria. The first of these was support for the country's two most structurally problematic regions in Northern Moravia and Northern Bohemia. Planning and implementation for these projects was done exclusively by the Commission and the central government (and its bodies at the regional level). Thus, the partnership principle was not applied. More- 
over, the funds earmarked for the projects in these regions were rather limited. $^{7}$

A more substantial initiative was the Phare cross-border co-operation (CBC) programme, which was launched in 1994 to support co-operation between Czech border regions and those of neighbouring countries. 'Gradually, during 1995-1999, the [CBC] programme became the most important part of the Phare programme with respect to financial means, and thus the most significant form of the EU assistance to the Czech Republic' (WME, 2000, p. 3). From 1994 to 1996, overall responsibility for implementation of the CBC programme was with the Ministry of Economics. After its creation in 1996, the MRD took over responsibility for this programme.

The EU's guidelines for the CBC programme were flexible as far as the design of its implementing structures was concerned. However, one of the main institutional conditions was the largest possible decentralization of competencies and decision-making to regional and local actors. This was because the initiative was modelled on the EU's Interreg programme, although full compatibility was not achieved. Thus, the partnership principle was applied when setting up the programme's organizational structure. Regional and local actors were represented on regional-level steering committees that prepared the programme and approved its financing proposals. For implementation of the CBC programme, the Czech government initiated the creation of new cross-border structures ('Euroregions'). These were established as voluntary associations of municipalities along, initially, the Czech-German and Czech-Austrian borders, and later also the Czech-Polish and Czech-Slovak borders, to fulfil the programme's criteria for decentralization (MRD, 2001a, p. 24).

Even greater decentralization was applied in the CBC sub-programme, small projects fund (SPF), whose main goal was to support non-investment activities (so-called 'people to people projects') in the various border areas. The MRD, as the national administrative body responsible for Phare CBC, decided on a maximum degree of decentralization from the national to regional level in this programme. While the MRD and Centre for Regional Development are responsible for overall programme preparation and implementation, regional-level bodies are directly involved in programme decision-making, administration and evaluation. This unprecedented level of decentralization led the Commission to recommend the Czech CBC-SPF to other candidate countries as a model for their own programmes (WME, 2000,

\footnotetext{
${ }^{7}$ See Ministry of Finance (1996). Phare started to finance projects in Northern Moravia in 1992, with the annual allocation of ECU 4 million. Support for Northern Bohemia followed in 1993, with an allocation of ECU 2 million.
}

(c) Blackwell Publishers Ltd 2002 
pp. 1-13).

Major changes to Phare came in response to the Luxembourg European Council's decision in December 1997 to begin entry negotiations with six of the 12 candidate countries. Anticipating this decision, the Commission adopted new Phare guidelines based on accession-led programming. From 1998 on, Phare support focused on the pre-accession priorities set out in the accession partnerships drafted by the Commission for each candidate state and the corresponding national programmes for the adoption of the acquis. The orientation of the revised programme was centred on two activities: institution-building (including 'twinning' 8 and technical assistance) and investment support. The 'accession-driven' phase of the Phare programme was also more demanding in that it required co-financing of investment projects from CEEC sources.

Preparation for EU regional policy was a key medium-term objective of the Czech accession partnership, and this found reflection in the Phare national programmes for the Czech Republic for 1998-2001. Funding was provided for the establishment of a national development strategy, and for the creation of a legal and institutional support structure for the structural and cohesion funds. The latter covered activities ranging from the adaptation of structural funds regulations, competition rules, financial controls, and the preparation of strategic programming documents, to support for the establishment of management and monitoring structures (Commission, 1998c, p. 4). A special emphasis was put on training. Under the Phare project "preparation for structural policies', training institutes were established in all eight NUTS II regions. In the 2000-01 period these institutes trained some 1600 officials in the administration of the structural funds (Commission, 2001c). Further training activities were implemented under subsequent Phare programmes.

In order to test the implementation of investment projects in a manner compatible with EU practice, Phare also funded pilot projects in two microregions (Jeseníky and Haná). The main goal of this exercise was to create regional and local institutions capable of implementing structural and cohesion fund projects and to transfer their experience to the NUTS II level. These capabilities would include: the ability to set up a structural funds secretariat; the collection and selection of good-quality, fundable projects; effective project administration; and adequate co-financing of projects (Ministry of Finance, 2001, pp. 7-8).

Additional pilot projects were initiated in the NUTS II regions of NorthWest Bohemia, Moravskoslezsko and Central Moravia under Phare 2001. The

8 Twinning involves seconding officials from EU Member States to selected institutions (usually ministries) in the candidate countries. In the Czech Republic the twinning programme has been gradually extended to the regional level, to include regional bodies such as Regional Councils, RDAs and local government agencies.

c B Blackwell Publishers Ltd 2002 
objective of these projects was to prepare for the structural and cohesion funds by testing a grant scheme to promote economic and social cohesion. The regions selected and priorities to be addressed by this project are based on the NDP, as submitted to the Commission by the Czech government in January 2000, and the relevant ROPs. In the next stage these activities will be extended to all NUTS II regions, resulting in the adoption and implementation of approximately ten concrete project proposals for each region that satisfy the requirements of the structural funds and are in line with the NDP and the national rural development plan (RDP), as well as the relevant ROP priorities. These projects should be proposed for Phare co-financing under the 2003 National Programme (Commission, 2001c, p. 13).

The future orientation of pre-accession aid in the period up to 2004 (the prospective date of accession for the Czech Republic) will be even more focused on preparing for the structural and cohesion funds. This was reflected by the introduction of two new pre-accession instruments in 1999: Sapard, in the field of agriculture and rural development; and Ispa, in the field of transport and environmental infrastructure.

\section{Ispa and Sapard}

The introduction of Ispa and Sapard began a new phase in the pre-accession preparations, allowing for more specialization and providing a clearer orientation of the individual programmes. As from 2000, Phare would focus mainly on economic and social cohesion, with an emphasis on institution-building, in particular through twinning and related investment support. It would no longer provide investment support for transport, the environment, or rural development, since these areas fall within the scope of the other two instruments (Commission, 1999b, pp. 8-9).

Ispa was designed to emulate the cohesion fund, in that funding would be used for infrastructure development in the transportation and environment sectors. Also resembling the cohesion fund, the institutional framework for Ispa is highly centralized. ${ }^{9}$ Support provided under the programme is given at the national level, with funding going to the relevant government ministries. The Commission is responsible for programming, and the Commission delegations in the candidate states are responsible for implementation. In the Czech Republic, the Ministry for Transport is responsible for projects in the transport sector, and the Ministry for Environment for projects in the environmental sector. These two ministries prepared and presented the Czech Republic's strategies for transport and the environment (compatible with the priorities of the Czech accession partnership) to the Commission. The structures to

${ }^{9}$ For details, see Ministry of Finance (2001, pp. 25-6).

(c) Blackwell Publishers Ltd 2002 
co-ordinate the programme include the national Ispa co-ordinator (Deputy Minister for Regional Development), who chairs the highest body - the Ispa Monitoring Committee. The members of this committee include representatives of relevant ministries, implementation agencies, the Commission, and international financing institutions (involved in co-financing Ispa projects). The work of the Ispa Monitoring Committee is assisted by the Ispa Co-ordination Committee, Ispa sectoral working groups, the sectoral authorizing officer, and the Ispa implementing agency.

Because it is modelled on the cohesion fund and not the structural funds, the partnership principle does not apply to Ispa. Although non-governmental organizations participate in the work of the sectoral working groups, regional and local actors are not represented in these bodies or other Ispa administrative structures.

In contrast to Ispa, Sapard was designed to function along the lines of a specific structural funds programme - the 'guidance' section of the European agricultural guarantee and guidance fund (EAGGF). ${ }^{10}$ Thus, it is the only truly decentralized pre-accession instrument. Czech authorities have overall responsibility for the programme's management and implementation. The Commission is not involved in programming, and only enters the programme to control its activities ex post. This is in sharp contrast with its role in the Phare and Ispa programmes, where the Commission approves the project implementation ex ante. ${ }^{11}$

In October 2000, the Commission approved the Sapard programme's key strategic document, the RDP of the Czech Republic (2000-06). The RDP was developed and proposed by the Ministries for Agriculture and Regional Development, which have joint responsibility for the programme at the national level. Sapard was due to begin operation in the Czech Republic in January 2000 , but this has been delayed by more than two years because of disagreements between Prague and Brussels over accreditation of the national Sapard Agency (Euro 2001, p. 34).

Because it is modelled on a structural funds programme, the principle of partnership is applied within the institutional and administrative framework of Sapard. The work of the Sapard National Monitoring Committee is assisted by the Regional Monitoring Committees set up in all eight NUTS II regions. The representatives of NGOs and regional authorities participate in

10 For details, see Ministry of Finance (2001, pp. 27-9). Similar to the EAGGF 'guidance' section, Sapard's objective is to support rural development and modernization, as well as tourism and agri-food industry projects.

${ }^{11}$ However, Phare and Ispa will be fully decentralized before accession by EDIS (extended decentralized implementation system), which is based on Council Resolution No. 1266/1999. The present ex ante control mechanisms will be replaced by the expost system already applied to Sapard, and Czech authorities will have overall responsibility for programme management and implementation. 
their work. The implementing Sapard agency is also decentralized, with branch offices operating in the NUTS II regions. Because of the delayed operation of the Sapard programme in the Czech Republic, however, there has been little opportunity to observe how these regionalized structures work in practice.

\section{The NDP for 2004-06}

Another area in which the partnership principle is supposed to be applied is preparation of the NDP, the main strategic planning document for pre-accession structural assistance and the structural funds.

Work on the NDP began in April 1998, with a government resolution (No. 235) outlining the basic principles of regional policy in the Czech Republic and calling for the establishment of a regional development strategy and related legislation by mid-1999. A follow-up resolution in June 1999 (No. 417) created the institutional structure for drafting regional policy programming documents, with specific attention to the issue of partnership. Government resolution (No.714) in July 1999 established the sectoral and regional priorities of Czech regional development policy for the 2000-06 period, and in December 1999 a first version of the NDP was approved and sent to the Commission. A revised version, containing eight ROPs and six sector operational programmes (SOPs), was submitted to the Commission in July 2001.12

After evaluating the document the Commission recommended that the Czech government decrease the number of operational programmes to be included in the plan, emphasizing the need to concentrate on a lesser number of priorities and focus attention on the most pressing problems of the country's economic and social development in the first years after accession. The Commission's position was reflected in its 2001 regular report: 'the Czech authorities should urgently take a number of fundamental decisions on the implementation of structural funds Programmes, most notably on the number of Operational Programmes' (Commission, 2001b, p. 82). The Commission, however, did not specify how concentration should be achieved, whether by decreasing the number of ROPs or the number of SOPs.

The Commission's position became more specific in subsequent consultations with the Czech government. During these talks, the MRD indicated that it strongly opposed merging some of the SOPs, and expressed its preference for merging the eight ROPs into a single regional operational programme (SROP). This view was endorsed by the Commission. In May 2001, the govern-

\footnotetext{
12 The SOPs identified in the NDP are: (1) strengthening the competitiveness of industry and business services; (2) development of technical infrastructure; (3) human resource development; (4) environment; (5) rural development and multi-functional agriculture; and (6) tourism.

(c) Blackwell Publishers Ltd 2002
} 
ment adopted a resolution (No. 470) that instructed the MRD to consult with the Commission on revising the NDP, and to prepare the final updated version for the government's approval before 30 June 2002.

In the second half of 2001, the MRD drafted two versions of the implementing measures for the NDP: (1) one featuring the S-ROP; and (2) one featuring seven ROPs plus a single programming document (SPD) for Prague. Both documents were distributed to the actors involved at both the national and regional level for discussion. In this discussion, a strong difference of views emerged. Generally speaking, the first scenario was supported by the MRD and the Commission, the second by the regions.

The S-ROP scenario is based on the assumption that the MRD will become the primary managing authority for structural funds programmes. The key position of programme manager will be taken up by a high-ranking MRD official. Each of the eight cohesion regions (Regional Councils) would send one representative to the managing committee. The relationship between the managing committee and the cohesion regions is defined in a rather vague way. The document gives the regions the right to express their views via recommendations on any issue connected to the carrying out of the programme. On the other hand, it states that the task of the Regional Councils is to contribute to the effective realization of the programme and fulfilment of its goals and act in line with the decisions adopted by the managing authority (MRD, 2001b).

This is in sharp contrast with the management structures proposed under the 'seven ROPs plus SPD for Prague' scenario, where the overall management responsibility for the programme is fully with the Regional Councils (MRD, 2001b). The regions feared that adoption of the centralized S-ROP scenario would undermine their ability to fulfil their priorities and diminish their role in administering the structural funds at the regional level. Some officials, when commenting on this debate, expressed concern that their views were not taken into serious account by the government. ${ }^{13}$ Similar concerns were reflected in the Commission's 2001 regular report:

The partnership principle has been applied during the drawing up of the NDP, but has yet to include comments from the self-governing regions. Further attention is needed to ensure there is sufficient representation from economic and social partners and other relevant bodies. Attention needs to be paid to information flows and dissemination methods as well as the time needed to incorporate wide-ranging views into documentation, formulating strategic aims and priorities. Application of the partnership principle in the NUTS II-level Regional Development Committees has to be ensured. (Commission, 2001b, p. 82)

${ }^{13}$ Interviews with government officials of the Olomouc region, December 2001-January 2002.

(c) Blackwell Publishers Ltd 2002 
Nevertheless, in a resolution (No. 102) adopted in January 2002 the government decided to adopt the S-ROP scenario promoted by the MRD, and instructed the MRD to prepare the S-ROP and SPD for the Prague region by 31 October 2002 (Czech Republic Government, 2002). In the explanatory report attached to the document, the MRD justified its choice of the S-ROP option in terms of the Commission's recommendations and Brussels' preference for expediency and efficiency over decentralization:

Due to the fact that there will be only a three-year period for realisation of the programmes after the expected accession of the first candidate countries in 2004, [the Commission's] recommendations were influenced by efforts to effectively utilise the resources at the disposal of the new Member States to a maximum extent. Any delays in the negotiating process and the realisation of the programming documents would lead to non-utilisation of the allocated funds ... . The Commission's key recommendations for programming in the field of economic and social cohesion concern the introduction of a transparent and simple system of operational programmes and a related system of implementing structures. Specifically, it concerns the following: minimalising the number of prepared operational programmes and definition of their contents, building administrative capacities for the implementation of programmes, decisions concerning the managing and paying authorities and the strengthening of absorption capacities in the regions. (MRD, 2002, p. 2)

The government's decision significantly strengthened the position of the MRD (vis-à-vis the regions) within the structures established for administering the structural funds. The regions, of course, were very disappointed and continued to question the decision. One regional governor, Jiri Sulc of the Ústecky $k r a j$, has argued that '[regional policy] decisions should be taken in the regions'. While admitting that the S-ROP scenario allows the regions to participate, he added that 'still, there will be one central committee. I have no interest in influencing the matters of other regions' (Euro 2002, p. 25). Another regional leader, Jan Brezina - governor of the Olomouc kraj and chairman of the Regional Council for the NUTS II region of Central Moravia - has argued that 'the S-ROP scenario does not represent a good solution, because it delays by several years the opportunity for the regions to gain experience with the application of the structural funds.' 14

The debate over the NDP for 2004-06 suggests that future co-operation between the MRD and the regions in administering the structural funds might be hindered by differing perceptions of their policy roles. It also illustrates the different understandings of the partnership idea held by central and regional government authorities. For the former, partnership is achieved through

14 Interview in March 2002.

(c) Blackwell Publishers Ltd 2002 
the representation of regional authorities in centralized management agencies and their adherence to the policy decisions of national-level bodies. For the latter, partnership requires the effective devolution of regional policy administration, with management decisions taken at the regional level by regional actors and bodies. The Commission has thus far played a rather ambiguous role, promoting the partnership concept in principle, yet discouraging its application in practice by emphasizing the need for expediency and efficiency in pre-accession preparations.

\section{Conclusion}

This article has examined the impact of EU enlargement on regionalization in the Czech Republic. Examination of this question was prompted by the debate on the EU and regionalization in the current Member States, as well as the conditionality requirements of EU accession. A reasonable starting hypothesis - given the institutional and administrative requirements of EU regional policy, the underdeveloped status of regional governance in the CEECs, the pressure these countries are under to adjust to EU norms and rules within a short period of time, and the Commission's support for regional self-governance and the principle of partnership - was that EU influence would be an important factor promoting regionalization and decentralization in the Czech Republic and other CEECs in the period before accession.

This study has found, however, that the EU's impact on regionalization in the Czech Republic has thus far been limited and highly ambivalent. On the one hand, the EU has supported the creation of a new system of regional selfgovernance in the Czech Republic, one that closely matches the Commission's own ideological preferences for democratically elected regional bodies. While it is difficult to say just how important the EU's role in the regional reform debate was, the Commission's views and the prospect of accession probably helped to overcome domestic opposition to decentralization and accelerated the regionalization process in the Czech Republic. The EU has also required the creation of regionalized structures for administering regional development programmes after accession, for instance the Regional Councils and Regional Development Committees. These structures will be the focal mechanisms for partnership, the EU's requirement that regional and sub-national actors be fully involved in the management of structural funds programmes.

On the other hand, the technocratic nature of the accession process, and the Commission's demands for efficiency and expediency in accession preparations and the implementation of EU programmes, have had a contrary effect, reinforcing the centralist preferences of national government authorities 
and undermining the Commission's nominal support for decentralization and partnership. This is seen most clearly in the case of the NDP, where the Commission's emphasis on efficiency supported the MRD's preference for a centralized approach to regional policy, against the wishes of regional authorities for a more decentralized model.

The findings of this article, therefore, confirm those of previous research on EU enlargement and regionalization in the candidate countries. A key argument of these studies is that the EU's impact on regionalization in the CEECs has been limited by the centralized nature of the accession process and its contradictory requirements and demands. In particular, the Commission's emphasis on the speedy completion of accession preparations and the efficient use of EU resources has created incentives for centralization and undermined its advocacy of decentralization and partnership (Brusis, 2001a, b; Grabbe 2001; Hughes et al., 2001).

As these studies also acknowledge, however, it is much too soon to reach any definitive conclusions about the EU's impact on regionalization in the CEECs, since these countries are still, after all, in the pre-accession period. EU membership could lead to greater regionalization and decentralization in the future, since after accession the new Member States will be obliged to apply fully the partnership principle in structural funds programmes, and regional interests could begin to mobilize within and around new but increasingly familiar regional structures. With this possibility in mind, what is the future potential for regionalization and decentralization in the Czech Republic, and what lessons in this regard can be drawn from the Czech experience in the pre-accession period?

Some clues about the potential impact of EU membership on regionalization in the Czech Republic can be gleaned from the experience of current Member States. As many studies have shown, the impact of EU regional policy on the domestic politics and governance of Member States has varied considerably, in accordance with such factors as size, governmental traditions and existing territorial arrangements (Bache, 1998; Jeffery, 1997; Börzel, 1999; Benz and Eberlein, 1999; Evans, 2001). In small countries, or countries with highly centralized political systems, such as Portugal, Ireland, Greece, France and the UK, EU policies have not (yet) led to significant decentralization or the empowerment of regional actors. In most cases, this is because national governments have successfully maintained their dominance and exercised a 'gatekeeper' function with respect to EU policies. In some larger countries, however, and countries with regionalized political systems or in which bottom-up demands for more regional autonomy were already great - such as Spain, Italy, Germany and Belgium - EU policies do indeed appear to have promoted greater regionalization and decentralization. 
The Czech Republic is neither a large country, nor one with a tradition of regional self-government. Like Sweden, Ireland, Finland, Portugal, the Netherlands, France and other Member States, it is a unitary state with a tradition of centralized government. Nor does it have strong ethnic or regional divisions. The potential for regionally-based ethnic conflict was largely eliminated with the 'velvet divorce' from Slovakia in 1993. While there is a recognizable Moravian identity (and latent Bohemian-Moravian tensions), it appears to be subsiding, and it is doubtful whether this is strong enough to be the catalyst for a new regional politics in the future. Regional differences of economic conditions are also minimal, excepting the unique position of the more dynamic Prague region.

One possible indicator of the limited potential for political regionalism in the Czech Republic was the result of the first elections for the new regional assemblies in November 2000. Voter turnout for the elections was very low, only 33.6 per cent (compared to 74 per cent for the 1998 national elections for the Chamber of Deputies), and parties which opposed the creation of the new regions - the Civic Democrats of former Prime Minister Klaus and the Communists - actually received an absolute majority of the vote cast (51 per cent). ${ }^{15}$ Thus, it is apparent that the new regional governments have a long way to go before acquiring the popular legitimacy and support that will allow them to become serious political actors and focal points for political mobilization at the regional level. The role of regional authorities in administering EU structural aid could bolster them in this regard, however.

The Czech experience with pre-accession aid programmes also indicates the central government's determination to exercise a 'gatekeeper' function and minimize the decentralizing impact of EU regional policy. With some exceptions, these programmes have been administered in a highly centralized fashion and the partnership principle has not been applied. Of course, most of these programmes were not modelled on the structural funds, and the application of the partnership principle therefore was not required. Nonetheless, the experience with these programmes reflects Prague's reluctance to involve regional and local actors more fully, and its preference for a centralized approach to structural development policy. The government's conflict with the regions in the preparation of the NDP is another indication of this approach.

The government's attitude towards decentralization is, of course, subject to change depending on its political complexion. In this regard, the new Social Democrat-Coalition government that was formed in July 2002 should be more decentralist, since both the Social Democrats and the centrist Coalition

\footnotetext{
15 Elections were held in 13 of the 14 regions, but not in Prague. This fact may have helped keep voter turnout low, since Prague is the national media centre, and the regional elections thus did not receive the media attention they might have otherwise. On the 2000 regional elections, see LaPlant et al. (2001).
} 
parties (the Christian Democratic Union-People's Party and the Freedom Union-Democratic Union) are more supportive of regionalization. Nevertheless, the general attitude of the Czech state and political elites towards decentralization seems to approximate what is found in France and other traditional unitary states in western Europe, and this could serve as a real barrier to further decentralization and regionalization in the Czech Republic in the future, despite the influence of EU regional policy.

\title{
Correspondence:
}

Dan Marek

Department of Politics and European Studies

Palacky University, Krizkovskeho 12

77180 Olomouc, Czech Republic

Tel: (+42) 0685633302

Fax: (+42) 0685225148

email: marekd@aix.upol.cz

\author{
Michael Baun \\ Department of Political Science \\ Valdosta State University \\ Valdosta, GA 31698, USA \\ Tel: 0012292595082 \\ Fax: 0012293335910 \\ email: mbaun@valdosta.edu
}

\section{References}

Bache, I. (1998) The Politics of European Union Regional Policy: Multi-Level Governance or Flexible Gatekeeping? (Sheffield: Sheffield Academic Press).

Benz, A. and Eberlein, B. (1999) 'The Europeanization of Regional Policies: Patterns of Multi-level Governance'. Journal of European Public Policy, Vol. 6, No. 2, pp. 29-348.

Blazek J. and Boekhout, S. (2000) 'Regional Policy in the Czech Republic and the EU Accession'. In Bachtler, J., Downes, R. and Gorzelak, G. (eds) Transition, Cohesion, and Regional Policy in Central and Eastern Europe (Aldershot: Ashgate), pp. 301-18.

Börzel, T. (1999) 'Towards Convergence in Europe? Institutional Adaptation and Europeanization in Germany and Spain'. Journal of Common Market Studies, Vol. 37, No. 4, pp. 573-96.

Brusis, M. (2001a) 'Institution Building for Regional Development: A Comparison of the Czech Republic, Estonia, Hungary, Poland and Slovakia'. In Beyer, J., Wielgohs, J. and Wiesenthal, H. (eds) Successful Transitions: Political Factors of Socio-Economic Progress in Postsocialist Countries (Baden-Baden: Nomos), pp. 223-42.

Brusis, M. (2001b) 'Between EU Eligibility Requirements, Competitive Politics and National Traditions: Re-creating Regions in the Accession Countries of Central and Eastern Europe'. Paper presented at the Bi-Annual Conference of the European Union Studies Association, Madison, WI, 30 May-2 June.

Commission of the European Communities (1990a) EC-Czechoslovakia Relations (Background Report). ISEC/B16/90, Brussels, 5 April. 
Commission of the European Communities (1990b) The EC and Its Eastern Neighbours (Brussels: CEC).

Commission of the European Communities (1997a) 'Commission Opinion on the Czech Republic's Application for Membership of the European Union'. Document drawn up on the basis of COM(97) 2009 final, Bulletin of the European Union, Supplement 14/97 (Luxembourg: OOPEC).

Commission of the European Communities (1997b) The PHARE Programme: An Interim Evaluation. Europe Documents, No. 5.

Commission of the European Communities (1998a) 'Czech Republic Accession Partnership 1998' (Brussels: DG 1A).

Commission of the European Communities (1998b) 'Regular Report from the Commission on the Czech Republic's Progress Towards Accession' (Brussels: DG IA).

Commission of the European Communities (1998c) '1998 Phare National Programme for the Czech Republic'.

Commission of the European Communities (1999a) '1999 Regular Report from the Commission on the Czech Republic's Progress Towards Accession' (Brussels: DG Enlargement).

Commission of the European Communities (1999b) Overview of the Phare Programme and the New Pre-Accession Funds. Proceedings of a seminar held in September 1999 at the EU Information Centre in Budapest.

Commission of the European Communities (2000) '2000 Regular Report from the Commission on the Czech Republic's Progress Towards Accession' (Brussels: DG Enlargement), 8 November.

Commission of the European Communities (2001a) 'Second Report on Economic and Social Cohesion: Unity, Solidarity, Diversity for Europe, Its People and Its Territory.' Adopted by the European Commission on 31 January 2001 (Brussels).

Commission of the European Communities (2001b) '2001 Regular Report on the Czech Republic's Progress Towards Accession', SEC (2001) 1746 (Brussels: DG Enlargement), 13 November.

Commission of the European Communities (2001c) '2001 Phare National Programme for the Czech Republic'.

Commission of the European Communities (2002a) 'General Budget of the European Union for the Financial Year 2002'. Brussels/Luxembourg, January.

Commission of the European Communities (2002b) 'Enlargement of the European Union: Guide to the Negotiations Chapter by Chapter' (Brussels: DG Enlargement, March). Available at «http://www.europa.eu.int/comm/enlargement/negotiations/chapters/negotiationsguide.pdf», accessed 20 June.

Commission of the European Communities (2002c) '2002 Regular Report on the Czech Republic's Progress Towards Accession'. SEC(2002) 1402 (Brussels: DG Enlargement), 9 October.

Czech Republic Government (1998) 'National Progamme for Adoption of the Acquis Communautaire' (Prague).

Czech Republic Government (1999) 'Position Paper of the Czech Republic on Chapter 21: Regional Policy and Co-ordination of Structural Instruments'. Prague, November. 
Czech Republic Government (2002) 'Resolution No. 102/2002 on "Completion of the Preparation of Programming Documents and Establishment of Managing and Paying Authorities for Use of the Structural and Cohesion Funds"'. Prague, available at «WwW.mmr.cz/cz/rdp/opprog/uv102.html», accessed 23 Janauary.

Euro (2001) 'Program Sapard: Zakleté peníze'. No. 29.

Euro (2002) 'Lachnituv urad vyrostl v obra'. No. 5, p. 25.

Evans, A. (2001) 'Regionalism in the EU: Legal Organization of a Challenging Social Phenomenon'. Paper presented at the Conference on Regionalism in the European Union, EU Center of the University System of Georgia, Georgia State University Atlanta, GA, 20 April.

Grabbe, H. (2001) 'How Does Europeanization Affect CEE Governance? Conditionality, Diffusion and Diversity?'. Journal of European Public Policy, Vol. 8, No. 6, December, pp. 1013-31.

Hooghe, L. and Marks, G. (2001) Multi-Level Governance and European Integration (Lanham, MD: Rowman \& Littlefield).

Hooghe, L. (ed.) (1996) European Integration, Cohesion Policy and Subnational Mobilization (Oxford: Oxford University Press).

Hughes, J. Sasse, G. and Gordon, C. (2001) 'Enlargement and Regionalization: The Europeanization of Local and Regional Governance in CEE States'. In Wallace, H. (ed.) Interlocking Dimensions of European Integration (Basingstoke: Palgrave).

Jacoby, W. and Cernoch, P. (2002) 'The EU's Pivotal Role in the Creation of Czech Regional Policy'. In Linden, R.H. (ed.) Norms and Nannies: The Impact of International Organizations on the Central and Eastern European States (Blue Ridge Summit, PA: Rowman \& Littlefield).

Jeffery, C. (ed.) (1997) The Regional Dimension of the European Union: Towards a Third Level in Europe? (London: Frank Cass).

Jones, B.J. and Keating, M. (1995) The European Union and the Regions (Oxford: Oxford University Press).

LaPlant, J., Lach, J., Marek, D. and Baun, M. (2001) 'Decentralization in Central and Eastern Europe: Regional Assemblies in the Czech Republic'. Unpublished paper presented at the Annual Meeting of the Southern Political Science Association, Atlanta, GA, 10 November.

Marks, G. (1992) 'Structural Policy in the European Community'. In Sbragia, A. (ed.) Euro-Politics: Institutions and Policymaking in the 'New' European Community (Washington, DC: Brookings).

Marks, G. (1993) 'Structural Policy and Multilevel Governance in the EC'. In Cafruny, A. and Rosenthal, G. (eds) The State of the European Community, II: The Maastricht Debates and Beyond (Boulder, CO: Lynne Rienner).

Marks, G., Nielsen, F., Ray, L. and Salk, J. (1996) 'Competencies, Cracks and Conflicts: Regional Mobilization in the European Union'. In Marks, G., Scharpf, F. W., Schmitter, P. C. and Streeck, W. (eds) Governance in the European Union (London: Sage), pp. 40-63.

Ministry of Finance (1996) Program Phare v České republice 1990-1996, Centre for Foreign Assistance (Prague).

(c) Blackwell Publishers Ltd 2002 
Ministry of Finance (2001) Programy pomoci Evropských spolecenství Phare, Ispa, Sapard, Centre for Foreign Assistance, Prague.

MRD (1998) Zásady regionální politiky vlády České republiky (Principles of Regional Policy of the Government of the Czech Republic), Vol. 17, Prague.

MRD (1999) 'Preparation of the Czech Republic for the Implementation of EU Cohesion Policy from the Year 2000'. Structural Funds Series - Volume 5/99, 1st English edn, Prague.

MRD (2001a) Phare Cross-Border Co-operation Programme in the Czech Republic. Prague, January.

MRD (2001b) 'Implementační opatření v programových dokumentech regionálního rozvoje: Varianta A - jeden společný ROP'. Unpublished government working document, Prague.

MRD (2002) 'Completion of the Preparation of Programming Documents and Establishment of Managing and Paying Authorities for the Use of the Structural and Cohesion Funds'. Explanatory Report, available at «www.mmr.cz/cz/rdp/ opprog/zprava.html», accessed 5 January.

MRD (n.d.) 'Training for the Implementation of Structural and Cohesion Funds: SPP Training Strategy', National Training Fund, Prague.

Moxon-Browne, E. and Kreuzbergova, E. (2001) 'The Ambiguous Effects of EU Regional Policy on the Applicant States: The Case of the Czech Republic'. Unpublished paper, presented at the Conference on EU Regionalism of the EU Center of the University System of Georgia, Georgia State University, Atlanta, GA, 20 April.

Péteri, G. and Simek, O. (2000) 'Summary of Main Policy Issues'. In European Union Enlargement and the Open Society Agenda: Local Government and Public Administration, LGI Studies (Budapest: Open Society Institute), March.

Pollack, M.A. (1995) 'Regional Actors in an Intergovernmental Play: The Making and Implementation of EC Structural Policy'. In Rhodes, C. and Mazey, S. (eds) The State of the European Union, III: Building a European Polity? (Boulder, CO: Lynne Rienner), pp. 361-90.

Saradin, P. and Sulák, T. (2001) Krajské volby 2000 (Olomouc: Palacky University Press).

Sedelmeier, U. and Wallace, H. (1996) 'Policies Towards Central and Eastern Europe'. In Wallace, H. and Wallace, W. (eds) Policy-Making in the European Union (Oxford: Oxford University Press), pp. 353-87.

West Midlands Enterprise (WME) (2000) 'Developing and Implementing a Programme: The Case of Phare CBC, Small Projects Fund'. In Training of Trainers for the Implementation of Structural and Cohesion Funds (Prague: National Training Fund).

Yoder, J.A. (2001) 'Decentralization and Regionalization after Communism: Administrative and Territorial Reform in Poland and the Czech Republic'. Paper presented at the Annual Meeting of the American Association for the Advancement of Slavic Studies, Washington, D.C., 16 November. 
